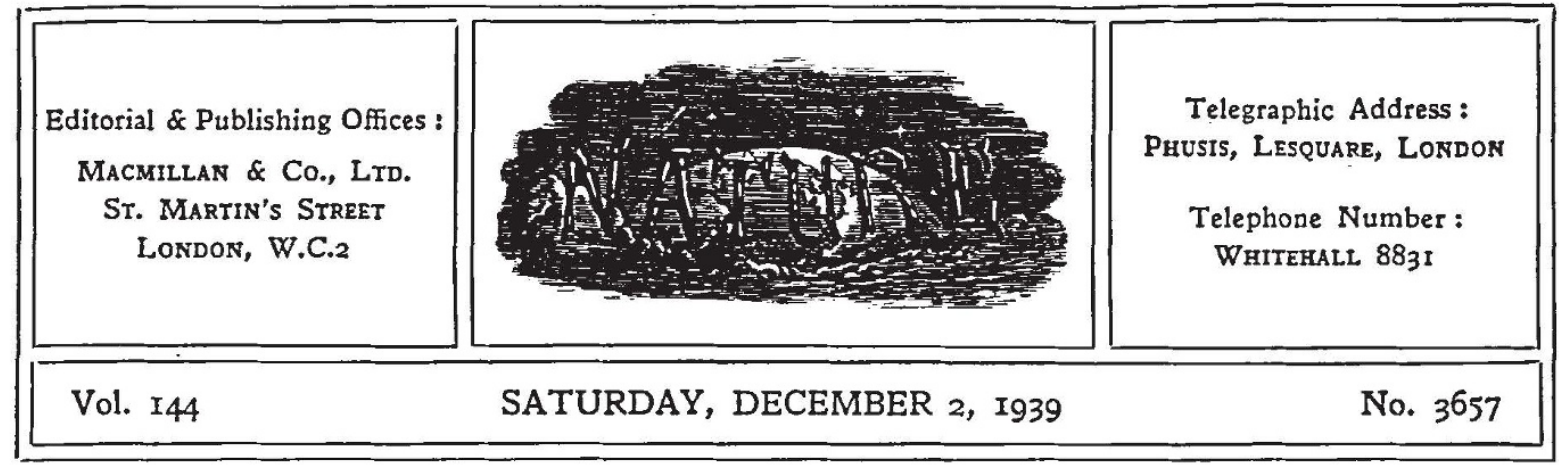

\title{
SCIENCE AND THE NEW EUROPE
}

$\mathrm{F}^{\mathrm{o}}$ OR some weeks past, much paper and ink have been expended in discussing the war aims of the Allies. Although the British and French Premiers and others have declared repeatedly and on various occasions that the purpose of tho Allies is to put an end to the constant aggressions of Germany, in the interests of peace among the European peoples, there are those who feel that, as thus stated, Allied aims are not sufficiently defined. Hence there is frequent difference of opinion as to whether, in arriving at the terms of a peace, it will be possible to discriminate between the Nazi Government and the German people. In this connexion, Mr. Chamberlain's restatement of the aims of Great Britain and her Allies in his broadcast of November 26 as "the defeat of that aggressive, bullying mentality which seeks continually to dominate other peoples by force, which finds a brutal satisfaction in the persecution and torture of inoffensive citizens, and in the name of the interests of the State justifies the repudiation of its own pledged word whenever it finds it convenient" should allay all doubt.

So clear and comprehensive a summing up of the forces to which the Allies are opposed, and to which they are determined to put an end, be they Nazi or characteristic of the German people at large, leaves no room for ambiguity or extenuation. In the pages of NaTuRE, however, and with the advancement and interests of scientific truth more especially in view, it is permissible to phrase our objective in even more precise terms without essential modification of substance, yet at the same time clarifying the issue. To every man of science it should be an article of faith that any view of the State and of the duty of the citizen to that State which require from the research worker, the man of science, or the teacher the distortion of scientific evidence, the suppression of any scientific truth, and the elimination of all freedom of thought which runs counter to the prevailing political theory, are abominations which must be destroyed, root and branch. Continental commentators on the war aims of the Allies, who are close observers of the German scene both at the moment and in historical perspective, have pointed out that while the German philosophy and mentality function in terms of 'power', Great Britain and France are thinking in terms of 'liberty'. Although the German people have been moulded by the Nazis to the ends of 'power politics' more drastically than ever before, it is no doctrine of to-day or yesterday. It goes far back in the history of the German people. How this should bear upon the attitude of those who have at heart the true interests of scientific thought and the advancement of scientific knowledge it is perhaps unnecessary to inquire. The moral is obvious.

Contributions to the recent discussion of war aims have brought to light many interesting differences of opinion and diversity of view. The 'New Europe' of which Mr. Chamberlain spoke is not one in which the map has been redrawn according to the ideas of the victors, but a Europe in which "the nations which inhabit it will approach their difficulties with good will and tolerance". Mr. Chamberlain went on to define the conditions of lasting peace as involving in the first place a full and constant flow of trade between the nations concerned, with an increased interchange of goods and services by which the standard of living could be improred; secondly, that each country would have the free and unfettered right 
to choose its own form of internal government, so long as that government did not pursue an external policy injurious to its neighbours; and thirdly, that in Europe armaments should be dropped as a useless expense, except in so far as needed for the preservation of internal law and order. As a corollary, he contemplated as necessary some machinery capable of conducting and guiding the New Europe in the right direction. Not unnaturally, Mr. Chamberlain did not feel called upon, nor indeed did he think it possible at this stage, to specify the kind of machinery which should be established for this purpose.

Although Mr. Chamberlain's foreshadowing of the possible course of post-War events must be still fresh in the minds of all, it is perhaps not superiluous that it should be recapitulated here. For the man of science this forecast bears a special significance. To him as a citizen it carries-as indeed it does to all-a message of promise and hope at a time when the very foundations of honour and decency of life in a civilized community are under grave threat. But for the man of science in the exercise of his special function as one whose work directly or indirectly comes ultimately to bear on the better organization of civilized life and its amenities, Mr. Chamberlain's words convey a deeper implication, and in a twofold sense. Of all the forces which in the interval between the last and the present War have made for international co-operation and mutual understanding between peoples-an essential condition of lasting peace-few have been more effectual than science. This has been due not merely to the effect produced by co-operation in research and the pooling of results, but it has arisen also out of the manner in which science has devoted itself to a world-wide, objective and impartial study of certain facts, and the application of the results of such study in efforts to raise the general standard among peoples in such matters as nutrition, personal and social hygiene, conditions of labour, production and exchange, and a hundred and one other problems which vitally affect the well-being of communitics and the happiness of their members. As must be inevitable after a great war, the need for these services will be intensified at the close of hostilities, and it may be assumed that to cope adequately with the conditions which will then prevail will demand a gigantic effort in which international co-operation alone will be equal to the strain.

More immediately, however, in Mr. Chamber- lain's New Europe it will be incumbent upon science, and more especially the biological and humanistic sciences, to place their knowledge, their methods of inquiry, and the results of their research at the disposal of the friendly conferences of which Mr. Chamberlain spoke, when they meet to adjust boundaries, to discuss the economic problems of productions, currency and exchange, and to consider those other problems with which they will have to deal to ensure the lasting peace for which we hope. It is equally essential that this body of specialized scientific knowledge should be at the service of that body, or machinery, which is to guide the development of the New Europe, whatever may be its form and whatever the authority which it may carry to enable its rulings to prevail. Only on this condition and by the utilization of such specialized knowledge to the full will it be possible to avoid the mistakes of a second 'Versailles'.

Political philosophies have alternated between 'force' and 'consent' in their analyses of the forces which contribute to the origin and growth of societies. Possibly a happy compromise between the two has in most instances brought about some state of equilibrium, a generally acceptable way of living. If force-the big policeman-is necessary to coerce the criminal, the perverse, and the members of an intractable minority, it is a force wielded in the interests of, and with the consent of, the majority. The preponderance of that majority and the unanimity of its consent to the exercise of force both as an instrument of, and as embodied in, law and order, must depend upon the recognition of a number of common aims among the members of the community and the extent to which each individual is prepared to curb his idiosyncrasies, should there be any to which the curb should be applied in the interests of other members. The same applies, or perhaps it would be more correct to say it is an ideal which should apply, in the relations between States and peoples. For it is the teaching of anthropology that each people, each national group, has its idiosyncrasies, like an individual-idiosyncrasies which are the product of a long history of cultural development in Europe going back to the Dark Ages, and indeed far beyond. Further, we learn from such studies that such a cultural heritage in the long run never submits to force, but itself vanquishes force in the end. Such modification as the cultural heritage may undergo in the course of development-and it is unquestionable that such transformations in 
the ethnic group have taken place on many occasions-this is brought about by cultural contact and cultural exchange no less than by the course of an internal cultural evolution (to use the term evolution in its more popular sense). Is this the solution of the German problem, the problem which to some seems insoluble without a change in the heart of that people as a whole, but of which at present there seems little prospect ?

The major problem of the post-War world will be the reconciliation of the cultural heritage, the national spirit of each ethnic group, with the common aim of a New Europe. If the guiding body or machinery of which Mr. Chamberlain spoke is to avoid the error of an earlier settlement, study of the problem which respects cultural and ethnic history must be invoked toward a solution. Then it may be possible to ensure international co-operation in a maximum of joint effort towards those common aims to which science, among other social forces, will point the way. The greater the common field in which co-operation can be brought about, the less the need is likely to arise of coercing the recalcitrant and the aggressor- by the threat of the big policeman-a major European war.

\section{AMERICAN MINERAL DEFICIENCIES}

Strategic Mineral Supplies

By G. A. Roush. Pp. xvii +485 . (New York and London: MIcGraw-Hill Book Co., Inc., 1939.) 33s.

$\mathrm{A}^{\mathrm{s}}$ a by-product of recent discussions about resources in essential raw materials, the word 'strategic' has acquired a specially limited significance in the United States. It refers to those materials which are not obtainable from within the national boundary in sufficient quantities to meet current industrial needs and therefore, in times of emergency, military necessities as well. The peace-time and war-time requirements of a modern State now differ quantitatively rather than qualitatively, and so the list of contraband materials has become extended very widely by all States.

The political atmosphere of the last six years has undoubtedly stimulated a specially intense examination of this subject, and study of the problem of self-sufficiency is naturally not an unpleasing theme to Americans ; for no other political unit has so few gaps in its defences to repair; has such small difficulties in securing supplementary supplies from outside; or is so well developed in its industrial configuration to absorb and turn to marketable or military account these imported strategic raw materials. For an industrialized country deficiencies in a few minerals are more serious than any shortcomings in vegetable pro. ducts, because the former are distributed over the globe in workable deposits without regard to climate or political boundaries; they cannot be made artificially; they cannot be transplanted; and only to a very limited extent, and then with some loss of efficiency, can the abundance of one material be made to make up for shortage in another.
In the United States ten minerals are listed by the War Department as 'strategic'; these are not, and are not likely, to be found there in quantity or quality to meet the demands which would certainly occur during war with any great Power. There are others officially classified as 'critical' which can probably be assembled in sufficient quantities by conservation and distribution control ; they are not, as Mr. Roush says, likely "to give rise to many headaches". Then there is the much longer pleasing list of 'essential' minerals which occur in obvious abundance in the States, some with a surplus for export.

With the exception of a short final few pages on the deficiencies of the other six great Powers, this volume is limited to a study of the American ten strategic minerals-manganese ore, nickel, chrom. ium, tungsten, tin, aluminium, antimony, mercury, platinum and mica-in addition to iodine and nitrogen, which are essential but can easily be obtained when necessary. This list also shows roughly the order of importance of these minerals for war purposes, and involuntary emphasis on the meaning of the word 'strategic' is shown by giving full consideration, in the first place, to manganese ore, the substance which gave the American steelmakers serious cause for anxiety during the War of 1914-18.

Very full data, graphically illustrated, are given for each of these minerals-the amounts required, their uses and ways of utilization, their occurrences, the partial substitutes obtainable for some of them, their outputs, prices, import tariffs and forms of control, followed in each instance by an appreciation, as the tactician would say, of the resultant domestic situation. As the editor, since 1914, of the annual publication well known as the Mineral 